Volume: 1 | Number 1 | pp. 91 - 104

ISSN: 2633-352X (Print) | ISSN: 2633-3538 (Online) journals.tplondon.com/ijor

First Submitted: 4 May 2020 Accepted: 1 November 2020

DOI: https://doi.org/10.33182/ijor.v1i1.982

\title{
Islam, Catholicism, and Religion-State Separation: An Essential or Historical Difference?
}

\begin{abstract}
Ahmet T. Kuru ${ }^{1}$
Abstract

There exist severe restrictions over religious dissent in most Muslim-majority countries. This problem is associated with the alliance between religious and political authorities in these cases. I argue that the alliance between Islamic scholars (the ulema) and the state authorities was historically constructed, instead of being a characteristic of Islam. Hence, the essentialist idea that Islam inherently rejects religion-state separation, whereas Christianity endorses it, is misleading. Instead, this article shows that the ulema-state alliance in the Muslim world was constructed after the mid-eleventh century, as well as revealing that the church-state separation in Western Europe was also historically institutionalized during that period. Using comparative-historical methods, the article explains the political and socioeconomic backgrounds of these epochal transformations. It particularly focuses on the relations between religious, political, intellectual, and economic classes.
\end{abstract}

Keywords: Islam; Catholicism; separation; ulema; state.

\section{Introduction}

Most Muslim-majority countries have serious problems regarding freedom of religious dissent. ${ }^{2}$ Twothirds of 49 Muslim-majority countries in the world have laws punishing apostasy or blasphemy (leaving or insulting Islam) in various ways, from prison to execution (Kuru, 2020). In a recent report, Pew Research Center documents religious restrictions around the world. Although Muslim-majority countries constitute only about a quarter of all cases in the report, they constitute over three-quarters of the cases "with most restrictive laws and policies toward religious freedom."3

Religious freedom requires a certain level of religion-state separation. If the state fully establishes a particular religion, this inescapably means legal, financial, and discursive discriminations against those who do not follow that religion. Such an establishment implies restrictions even upon those who believe in and practice the established religion, but in a different way than defined by the state. According to a well-known perception, Islam inherently rejects religion-state separation. If this is true, it is impossible to fully achieve religious freedom, particularly for those who hold dissenting views, in the Muslim world.

According to this perception, Christianity essentially embraces religion-state separation, whereas Islam rejects it. Those who promote this perception provide some textual evidence. They quote a

\footnotetext{
${ }^{1}$ Ahmet T. Kuru, PhD, Professor, San Diego State University, California, United States. E-mail: akuru@sdsu.edu

2 The research for this article has been funded by the Religious Freedom Institute under the Freedom of Religious Institutions in Society Project, a three-year initiative funded by the John Templeton Foundation. Portions of this article were adapted from Kuru 2019; they were used with permission.

${ }^{3}$ Eighteen out of twenty-two cases with the most restrictive laws and policies are Muslim-majority. Pew Research Center, 2019. See also Philpott, 2019; Fox, 2020.
} 
Biblical phrase, “render unto Caesar the things that are Caesar's, and unto God the things that are God's" (Luke 20: 25), to show church-state separation in Christianity (Lewis, 1991: 15; Huntington, 1996: 70). And they misquote Prophet Muhammad by attributing a maxim to him: "Religion and royal authority are twins. Religion is a foundation and the royal authority is a guard. Anything that has no foundation collapses and that has no guard perishes" (Rosenthal, 1958: 8, 39). In reality, this maxim belongs to the founding king of the Sasanian Empire, Ardashir I (r. 224-42) (Maçoudi, 1863 [947]: 162; “Le Testament d'Ardasir," 1966: 49; Nizam al-Mulk, 1978 [c. 1090]: 60). Several of Ardashir's sayings were translated into Arabic and this particular one has been used to justify the partnership between Islamic scholars (the ulema) and Muslim rulers, or what I call the ulema-state alliance (al-Ghazali, 2013 [1095]: 231).

Even if this statement had been a true hadith — a record about Prophet Muhammad's words and actions - it would not have mattered much, because religion-state relations in both Christianity and Islam are too complex to be explained by a Biblical phrase or a hadith. This article will show this complexity by exploring the changing characteristics of religion-state relations in the Muslim word and Western Christendom with a focus on the transformations that began in the mid-eleventh century in both regions.

In reality, Islam had a history of a certain religion-state separation. Between the eighth and mideleventh centuries, Islamic scholars generally regarded close entanglements with political authorities as corrupt. The ulema preferred to be funded by the private sector, especially commerce. Only a small minority of them worked as state servants. During that period, the Muslim world produced creative scholars in both religious and non-religious sciences. Western Europe, in contrast, was under the hegemony of the Catholic clergy and the military aristocracy. Unlike the Muslim world, Western Europe lacked influential intellectual and merchant classes.

Around the year 1050, however, a new political system emerged in the Muslim world. Instead of the old system, which allowed a certain level of private economic entrepreneurship and religious diversity within Islam, the new political system—represented primarily by the Seljuk Empire (1040-1194)— centralized both the economy and Islamic educational institutions. A major characteristic of the new system was the alliance between the ulema and the military rulers. The ulema-state alliance declared "unorthodox" views of Muslim philosophers apostasy. An institutional basis of this alliance was a new network of madrasas_-schools of Islamic law and theology (Kuru, 2019: 71-116).

Again, around the year 1050, Western Europe began to experience a process almost in the opposite direction. From the mid-eleventh to the mid-twelfth century, the Catholic Church and various kings tried to dominate one another. The failure of these attempts led to the institutionalization of the church-state separation. This contributed to the increasing balance of power among various institutions in Western Europe, which eventually led to philosophical and religious diversity (Berman, 1983; Bloch, 2014 [1940]; Tierney, 1988 [1964]).

This article will explain that the ulema-state alliance was not an essential part of Islam; instead, it was constructed during and after the mid-eleventh century. Similarly, the church-state separation in Western Europe was a result of a historical process, which began in the mid-eleventh century. In social science terminology, for both Muslim and Western worlds, the second half of the eleventh century was a "critical juncture" (Mahoney and Rueschemeyer, 2003; Kuru 2009, 27-28), which left a "path-dependent" legacy for subsequent centuries. This legacy has had major implications for religious and political systems in both regions. 


\section{The Muslim World: The Ulema-State Separation}

\section{Scholars, Rulers, and Merchants}

Between the eighth and mid-eleventh centuries, the ulema were largely trying to keep their financial independence from state authorities and regarded close relations with them as corrupt. This attitude had a historical background. In the mid-seventh century, there occurred a civil war between Ali, the fourth caliph and the son-in-law of the Prophet, and Muawiya, the governor of Damascus. This and the subsequent tragedies, including the death of thousands and the murder of Ali and his son Hussein, led Shii and many Sunni Muslims to be disenchanted about the relationship between political power and religious morality (Hodgson, 1974a: 212-223; Morony, 1984: 467-506).

Muawiya established the earliest dynasty in Islamic history — the Umayyads (661-750) — based on the persecution of the Prophet's family members. Unlike the charismatic, personal, and religious authorities of Prophet Muhammad and four succeeding caliphs (Abu Bakr, Umar, Uthman, and Ali), the authority of Muawiya was institutionalized and largely "secular." Muawiya was the first in Islamic history to use a throne and bodyguards (Ibn Khaldun, 2005 [1377]: 216; Morony, 1984: 93). Several scholars define Muawiya as the first real state-builder in Islamic history, and most Umayyad rulers as those who secularized political authority by prioritizing the raison d'état (Abdel Rezak, 2012 [1925]; Rahman, 1968: xx; Djaït, 1989: 411; al-Banna, 2003: 4-9).

The Abbasids (750-1258) replaced the Umayyads with a bloody revolution. They were not very different from the Umayyads in terms of lacking effective religious legitimacy. Both the Umayyad and the Abbasid rulers called themselves "caliphs," claiming to be the successors of the Prophet (Crone and Hinds, 1986). But the Shii ulema largely refused their legitimacy, in both the religious and political grounds, while most Sunni ulema regarded them as political rulers per se. For these Sunni ulema, the true "caliphs" with religious legitimacy were only the first four after the Prophet and before the Umayyads (Abou El Fadl, 2009: 94-95; Lapidus, 1975: 369).

The disagreements between political and religious authorities at that time were visible in the lives of not only Shii ulema, including Jafar al-Sadiq, but also such prominent Sunni ulema as the founders of four Sunni schools of law_Abu Hanifa, Malik, Shafii, and Ahmad ibn Hanbal—who refused to serve the state. ${ }^{4}$ Because of their principled-based rejection of political rulers' demands, Jafar al-Sadiq was poisoned to death, Abu Hanifa died in prison, Malik was whipped, Shafii was detained and chained, and Ibn Hanbal was beaten in prison (al-Nadim, 1970 [987]: 494; al-Ghazali, 2015 [c. 1097]: 72-76; Afsaruddin, 2008: 96-105, 137-141).

Abu Hanifa's (d. 767) life-story shows how the early ulema insisted on their independence from political authorities even if they faced punishment. He rejected the Abbasid Caliph Mansur's personal offer of judgeship with the excuse of not being qualified. The Caliph got angry and called him a liar. Abu Hanifa replied that a liar could not be appointed as a judge. Mansur swore an oath that he would make him accept the post. Abu Hanifa similarly swore an oath that he would never accept it. Consequently, Abu Hanifa was imprisoned and then poisoned to death (Nadwi, 2010: 39).

It is true that some Sunni ulema, such as the two prominent students of Abu Hanifa-Abu Yusuf and Shaybani-served the state as judges (Lambton, 1981: 55-58). Yet these exceptions did not represent the mainstream characteristic of the ulema-state relations between the eighth and mideleventh centuries. Let alone receiving money and positions, some ulema refused to make even

${ }^{4}$ Shafii served as a judge in his youth, though he later regretted having done so. See Fadel, 2011: 117. 
gestures. A governor in Central Asia asked Bukhari (d. 870)—who would become the most famous hadith scholar - to teach his children in his palace. Bukhari refused and replied that the ruler was welcome to send his children to his hadith circle. The annoyed ruler forced Bukhari into exile in a village, where he died (Abdul-Jabbar, 2007: 19).

Munir-ud Din Ahmed (1968: 229) analyzed the ulema's financial autonomy during this early period. In his words, "An exceedingly large number of scholars are reported to have rejected all financial help from authorities. This was done by the scholars in the first place to keep themselves free of governmental pressure." Other historians also note that many leading ulema of the time, including Ibn Hanbal and Sufyan al-Thawri, declared that it was forbidden for the ulema to take money from political rulers (Mez, 1937: 184).

Hayyim Cohen (1970: 16) conducted the most detailed analysis of this subject. He examined 3,900 ulema biographies from the eighth to the mid-eleventh century, from Egypt eastward. Cohen finds out that at that time the ulema were very different from the Christian clergy, because the ulema, except the judges and few other scholars, "functioned in an entirely private capacity, unappointed either by the authorities or by any religious institution ... received no emoluments and had to support themselves, which they did in a variety of ways." Most ulema or their families worked in commerce and industry, particularly as the following: merchants or artisans in the textile industry (22\%); those processing or dealing with food (13\%); miscellaneous merchants $(11 \%)$; those sold or made leather, metals, wood, or clay $(9 \%)$; those dealt with ornaments (e.g., jewelers) and/or perfumes $(8 \%)$; bankers, money-changers, and middlemen (5\%); and booksellers, book copiers, and paper sellers $(4.5 \%)$. Some ulema worked as teachers (especially tutors) $(8 \%)$, or investigators of witnesses $(3 \%)$. Only a small portion of them $(8.5 \%)$ worked as officials. ${ }^{5}$

Along the same line, Eliyahu Ashtor (1976: 111) emphasizes the connection between Islamic scholarship and commerce in the early Abbasid era: "Many merchants became . . interested in the sciences of Islam." In some cases, "their sons devoted themselves entirely to the scholarly life." Thus, "it can be seen from the study of the Arabic collections of biographies that most theologians of this period belonged to the bourgeois class, i.e. were merchants or sons of merchants." Roy Mottahedeh (1980: 135-137) analyzes parts of Iraq and Iran under the Buyid rule from the mid-tenth to mideleventh centuries. He stresses that the ulema wanted to distance themselves from the government. That was why "families whose ancestors had exercised riyasab [leadership] in the bureaucracy or the army of the central government did not produce many leading men of religious learning." Moreover, at that time the ulema were a "vaguely defined body of men" who had "little internal structure" and held multiple identities and occupations.

The autonomy of the ulema from political rulers was associated with other characteristics of Muslim societies, such as the presence of an influential class of merchants, a creative class of philosophers, and a certain level of religious freedom for Christians and Jews. None of these characteristics existed in Western European societies at that time.

\section{Muslims, Christians, Jews, and the State}

During the Umayyads and Abbasids, the lack of a hierarchical religious authority led to the emergence of numerous Sunni and Shii interpretations of Islam. In his well-known book, Shahristani (d. 1153)

\footnotetext{
${ }^{5}$ Other occupations, such as physician, lawyer, porter, mule driver, and hair-dresser, constitute the remaining 8 percent. Cohen, $1970: 36$ (Table A-I). The biographies of these scholars and their families reveal 410 different occupations, only 56 of which (less than $15 \%$ ) were "connected with official services." Cohen, 1970: 17, 45-61. See also Bulliet, 2009: 1-5, 43-44.
} 
(1984 [c. 1127]; 1986 [c. 1127]: 105-585) analyzes religions of his time. He classifies 73 different sects within Islam.

At that time, non-Muslim communities, particularly Christians and Jews, were actively participating in socio-economic life. ${ }^{6}$ In The Renaissance of Islam, Adam Mez (1937: 51, 418) elaborates that these communities had involvement with even government: during the tenth century, some Christians and Jews were workings as bureaucrats in the Abbasid state. Mez also notes that in Baghdad, Muslims were joining Christians' celebrations. In the ninth century, some caliphs ordered the protected subjects (mostly Christians and Jews) to show their lower social status in certain dress codes and vehicles, such as riding on mules and donkeys, instead of horses. In practice, however, these measures were not effectively implemented. Throughout the tenth century, these rules largely remained "dormant. With the ascendancy of orthodoxy in the 11th century they were once again taken more seriously” (Mez, 1937: 50; see also Goddard, 2000: chs. 3-4).

This diversity and relative toleration was not limited to Baghdad. According to Shelomo Goitein (1966b: 247), the Geniza documents (which were found out in a synagogue in Old Cairo and provide information about Jewish merchants in Muslim lands) reveal that in Cairo, Damascus, and Jerusalem, "Jewish houses often bordered on those of Muslims or Christians or both. There was no ghetto, but, on the contrary, much opportunity for daily intercourse. Neither was there an occupational ghetto."

Religious diversity and toleration did not mean the lack of religious persecution, even for certain Muslims. For instance, during the period of the mibna (inquisition), between 833 and 848, three consecutive Abbasid caliphs forced state servants and the ulema to confirm the rationalist idea that the Quran was God's creation, rather than his eternal, uncreated speech. ${ }^{7}$ Some leading ulema such as Ibn Hanbal (d. 855) refused to obey, despite threats of punishment and even execution. During the mibna, "the sources list a total of forty-eight persons who were subject to official interrogation" (Lapidus, 1975: 379; see also Zaman, 1997: 106-14).

Actions generally create reactions. This rationalist inquisition was backfired and it made literalist scholars, particularly Ibn Hanbal, popular. The following sections will examine how and why a literalist orthodoxy dominated the Muslim world after the mid-eleventh century. Before that, I will briefly mention the connections between religious freedom and intellectual/economic creativity.

\section{Religious Autonomy: Intellectual and Economic Dynamism}

From the eighth to the mid-eleventh century, religious autonomy, diversity, and toleration were associated with the existence of an influential bourgeoisie and productive polymaths in the Muslim world.

According to Goitein (1966a: 238-239), Muslim lands had an effective monetary economy, which provided encouraging conditions for Muslim and Jewish merchants. He cites a tenth-century writer who claimed that "[m]erchants are more powerful than viziers [ministers]" because "a bill of exchange was accepted with greater readiness than an allocation of income from taxes." He even characterizes the situation as a "bourgeois revolution." Goitein (1966a: 241) writes, "The "bourgeois revolution' of the Middle East during the early centuries of Islam had many repercussions on world

${ }^{6}$ The case of John of Damascus (675-753) shows how a Christian could become a world-renowned theologian under Muslim Umayyad rule. Similarly, in Baghdad, under the Abbasids, Yahya ibn Adi (893-974) became a famous Christian theologian, philosopher, and translator. Fakhry, 2004: 197-207.

${ }^{7}$ According to Mutazilis, to depict the Quran as timeless and not created was similar to how the Christians depicted Jesus. Corbin, 1986: 160; Melchert, 2006: 10. 
history. To mention just one: through it the Jews, who up to that time had been engaged mainly in agriculture and other manual occupations, were converted into a predominantly commercial people." Similarly, Maristella Botticini and Zvi Eckstein (2012: 55-56) explain in greater detail that the "fullfledged transition of the Jews from farming to crafts and trade took place" roughly between the years 750 and 900, under Umayyad, Abbasid, and Fatimid rule, where "Jews were legally permitted to own land ... and to engage in any occupation they wished."

In the early medieval period, Muslim merchants funded many ulema and philosophers. Muslim philosophers, or polymaths, made major contributions to various fields, such as mathematics, optics, and medicine. Their contributions included the development of Arabic numerals, the invention of camera obscura, and the distinction between smallpox and measles (Joseph, 2000; Lindberg, 1976; Pormann and Savage-Smith, 2007). Muslim merchants also led commercial and agricultural flourishing (Shatzmiller, 2011; Watson, 1983), which included the innovation of such economic instruments as the check and the bill of exchange (Braudel, 1982: 556; Van Zanden, 2009: 61; Bloom and Blair, 2002: 114). Even politically, Muslim merchants were influential (Lombard, 1975: 150). In the mid-tenth century, under Abbasid rule, merchants "constituted an international credit community that the government could abuse only at considerable risk" (Mottahedeh, 1980: 118).

A major transformation began in the mid-eleventh century. The relative separation between the ulema and the state started to deteriorate, a literalist Sunni orthodoxy became increasingly influential (al-Ashari 1953 [c. 935]), and the monetary economy was gradually replaced by a new system of the state allocation of land revenues. This transformation gradually caused intellectual and economic stagnation in the Muslim world (Kuru 2019, chapters 5-7).

\section{The Ulema-State Alliance}

The mid-eleventh century transformation had economic, political, and religious dimensions. Economically, diminishing agricultural revenues in Iraq had already weakened the old regime (Bonner, 2010: 354). In the eleventh century, the new economic regime emerged with the increasing usage of iqtas - tax farming and land revenue assignments to the military and other state servants. In subsequent centuries, various Muslim sultanates developed and used versions of the iqta system (Cahen, 1953; Lambton, 1991; Hodgson, 1974b: 46-52). Politically, the state structure gained a more militaristic form. Starting with the eleventh century, focusing on military conquests became another common characteristic of Muslim sultanates (Barthold, 1977 [1900]: 272-292; Starr, 2013: 332-335). These new economic and political systems marginalized the once-influential merchant class. The emerging alliance between religious and political authorities was based on these economic and political transformations (Kuru, 2019: 93-116).

There also existed a deep religious dimension of this transformation. In the first half of the eleventh century, Abbasid caliphs in Baghdad attempted to regain political power against the Shii rulers who dominated North Africa, Egypt, Syria, and even Iraq. To change this situation, two subsequent Abbasid caliphs called for the unification of Sunni sultans, ulema, and masses. They declared a creed, which defined a "Sunni orthodoxy." Those whose views were deemed to contradict this creed, including certain Shiis, philosophers, and rationalist theologians (Mutazilis), were declared to be apostates and faced the threat of execution (Mez 1937, 206-9; Hanne 2007, 71).

In the second half of the eleventh century, the Seljuk rulers allied with the Abbasid caliphs and the ulema to consolidate the Sunni orthodoxy and to eliminate Ismaili Shiis. Muslim philosophers were also targeted due to their heterodox thoughts. Ghazali (d. 1111), a genius member of the ulema, 
played a leading intellectual role in the attacks against Ismaili Shiis and philosophers (al-Ghazali, 1999 [1095]: 228-231). In several books, which have been widely read from that time to the present, Ghazali declared two leading Muslim philosophers, Farabi (d. 950) and Ibn Sina (d. 1037), apostates due to their three unorthodox views - that the world is eternal, God's knowledge encompasses only the universals, and the resurrection is only spiritual. Ghazali wrote that defending these views were punishable by death (al-Ghazali, 2000 [1095]: 226; see also al-Ghazali, 2013 [1095]: 241; al-Ghazali, 2002 [c. 1105]: 110; al-Ghazali, 1999 [c. 1108]: 62-3).

The institutional basis of the ulema-state alliance was a network of madrasas. The Seljuk grand vizier Nizam al-Mulk (r. 1064-92) patronized a madrasa in Baghdad, which became the pioneer of that network. These institutions were later called after him-the Nizamiyya madrasas. These madrasas were funded by waqfs (foundations). Nevertheless, madrasas could not be simply defined as private or independent, because political rulers and officials were the founders of the madrasas' endowments. Nizamiyya madrasas promoted Sunni orthodoxy and trained a particular type of ulema that would accept the service to the state (Ephrat, 2000; Arjomand, 1999).

The Seljuk way of combining the iqta system, the military state, and the ulema-state alliance emerged in Central Asia, Iran, and Iraq in the second half of the eleventh century. A century later, it was spread to Syria and Egypt under the Ayyubids and then Mamluks (Ibn Khaldun, 1967 [1377]: 435; Berkey, 1992: 130-46). Later, it became dominant in vast geography from the Balkans to India under the Ottomans, Safavids, and Mughals (Lapidus, 1996; Kuran, 2011: 128-131). These sultanates were militarily powerful, but they failed to revive early Muslims' intellectual and economic dynamism because they eliminated philosophers and marginalized merchants (Lapidus, 1984; İnalc1k, 1994).

I use the term "alliance" because there was a reciprocal relationship between the ulema and the state. The Ottoman Empire (1299-1922) was the case where the ulema-state alliance had the deepest institutionalization. In the Empire, the ulema had certain religious, legislative, judicial, and educational prerogatives. In some cases, the ulema even cooperated with the Janissaries in deposing sultans. Nonetheless, the sultans had executive powers, including coercion and finance, that they could use against certain members of the ulema (İnalc1k, 2000 [1973]: 63-64, 169-172). In sum, the Ottoman case reveals that the relationship between the ulema and the state meant a mutually beneficial partnership, rather than a one-way state dominance over the ulema, or vice-versa.

In sum, after the eleventh century, the ulema-state alliance used religious orthodoxy and state violence to suppress contenders. Threatened by execution in this world and eternal hellfire in the hereafter, many Muslims were discouraged from intellectual exploration outside the boundaries drawn by the alliance between religious and political authorities. Nonetheless, in Western Europe, a different process began in the eleventh century in terms of the relations between these authorities.

\section{Western Europe: The Church-State Separation}

\section{Western Europe and the Muslim World: A Brief Comparison}

Between the ninth and twelfth centuries, Western Europe had inferior scientific and socioeconomic conditions in comparison to the Muslim world. Regarding literacy, Muslim libraries in such cities as Baghdad, Cairo, and Cordoba had hundreds of thousands of books, whereas Western European libraries had fewer than 600 books (al-Nadim, 1970 [987]; Mez, 1937: 172; Harris 1995, 98). Muslims started to produce paper in the eighth century, while it took five more centuries for Western Europeans to do so (Bloom 2001, 45-9, 116; Kennedy 2005, 36; Glick 2005, 279-80; Kilgour 1998, 79). In terms of urbanization, around the year 1000, Muslim Cordova had the largest population 
$(450,000)$ in Europe, including Constantinople (300,000), whereas the largest Western Christian city, Palermo, had only 75,000 people (Chandler, 1987: 467-9). Baghdad was even bigger than Cordoba (Watson, 1983: 133; Lapidus, 2002: 56). Financially, Muslims began to mint gold coin in the early ninth century, four and half century before Western Europeans achieved to do that (Braudel, 1982: 559; Maddison, 2004: 73).

A major reason for this divergence was that thinkers and merchants enjoyed a relatively high social status in Muslim lands, whereas the clergymen and the military elite dominated Western Europe. According to Norbert Elias (2000 [1939]: 221), until the mid-eleventh century, there were only "two classes of free people" in Western Europe-the clergy and the warrior nobles. This situation began to change in the mid-eleventh century. Agricultural development, in particular, and economic growth, in general, led to the development of cities and the emergence of a free and flourishing merchant class. Marc Bloch (2014 [1940]: 75-8, 307, 372) also regards the year 1050 as a turning point in Western Europe. Until that time, he explains, townspeople were marginal because they depended on commerce that was undermined by ecclesiastical and knightly classes.

Another reason why Bloch (2014 [1940]: 370) refers to the mid-eleventh century as a turning point is the transformation of the relationship between the Catholic Church and the royal authority.

\section{The Eleventh Century Reform, or Papal Revolution}

In the second half of the eleventh century, several members of the Catholic Church claimed superiority over kings, while certain kings tried to dominate the Church. Neither side had a clear purpose of church-state separation. The struggles between the clergy and the royal authority caused not only doctrinal debates but also military conflicts. Cardinal Humbert-who also played a leading role in the Great Schism between the Catholic and Orthodox Churches in 1054-was a prominent defender of the Church's supremacy over royal authority. He argued, "Just as the soul excels the body and commands it, so the priestly dignity excels the royal" (Quoted in Tierney, 1988 [1964]: 35).

The Catholic Church established some rules to limit lay rulers' interventions in the ecclesiastical appointments. In 1059, a papal decree was issued about the pope's election by cardinals. Yet, Henry IV (r. 1054-1105), king of Germany and later Holy Roman emperor, insisted to hold the authority to appoint bishops. In response, in 1075, Pope Gregory VII (r. 1073-1085) issued 27 dictates, which asserted not only the Church's institutional independence, but also its supreme status. The dictates include the following: "That the Pope is the only one whose feet are to be kissed by all princes," "That he alone can depose or reinstate bishops," and "That he may depose Emperors" (Quoted in Tierney, 1988 [1964]: 49; Southern, 1970: 102). Consequently, Henry deposed Gregory, while Gregory excommunicated Henry. The struggles between various popes and monarchs continued in the early twelfth century. For example, King Henry V, the son of Henry IV, imprisoned the pope of his time. Despite such royal resistance, the Catholic Church's rulings during this revolutionary period created its institutional autonomy and have had long-lasting effects. Hence, they have been called the "Eleventh Century Reform” or the "Gregorian Reform” (Logan, 2013: 98-107).

According to Bloch (2014 [1940]: 114), before the Gregorian Reform "the sacred and profane had been almost inextricably mingled" in Western Europe. The reform meant a rupture for the separation "between the spiritual and the temporal," which would later be celebrated as "one of the greatest innovations introduced by Christianity." Bloch (2014 [1940]: 401) emphasizes that the Church leaders' goal in "separating the two powers so completely" was "to humble the rulers of men's bodies before the rulers of their souls." Brian Tierney (1988 [1964]: 86) also elaborates that during the eleventh-century struggles, kings tried to establish a "royal theocracy," while popes tried to found a 
"papal theocracy." Neither side was willing to simply render unto Caesar what is Caesar's, and unto God what is God's. Nonetheless, both sides failed to subdue the other. As an unintended consequence of this mutual failure, the separation between the Church and the royal authority became institutionalized (see also Tierney 1982: 10)

Harold Berman (1983: 87-103) goes even further than Bloch and Tierney and calls the reforms during this investiture conflict, which took place between 1075 and 1122, the "Papal Revolution." Before this revolution, the Catholic clergy largely supported the royal authority in a way that resembled Caesaropapism - the Byzantine system where the clergy recognize the royal authority as supreme and as combining the secular and religious powers:

Prior to the late eleventh century, the clergy of Western Christendom-bishops, priests, and monks-were, as a rule, much more under the authority of emperors, kings, and leading feudal lords than of popes...In addition to its political-economic subordination, the church was also subject in its internal structure to the control of leading laymen...At the same time, bishops and other prominent clergy sat in governmental bodies-local, baronial, and royal or imperial...The system was similar to that which prevailed in the Eastern Roman Empire, and which was later denounced in the West as Caesaropapism (Berman 1983: 88).

Berman (1983: 91) also gives numbers to support his depiction of church-state relations before the late eleventh century: "Of the twenty-five popes who held office during the hundred year prior to 1059 (when a church synod for the first time prohibited lay investiture), twenty-one were directly appointed by [German] emperors and five were dismissed by emperors.

Hence, there was no church-state separation in either Western or Eastern Christianity. The Orthodox Church never experienced a separation from the Byzantine state or, later, the Russian state. ${ }^{8}$ The Catholic Church, however, was transformed during the Papal Revolution. According to Berman (1983: 83), the Church "established itself as a visible, corporate, legal entity, independent of imperial, royal, feudal, and urban authorities." Berman (1983: 538-539) even argues that this revolution was not only chronologically earlier than subsequent epochal changes such as Renaissance and the Reformation, but also more important than them for the formation of the Western legal tradition.

More recently, Jan Luiten van Zanden (2009: 48) reiterated the significance of the Papal Revolution. He stresses that with this revolution "power within the Latin West would be divided between Pope and Emperor" and this division later became deeper with the rise of cities and other entities. Consequently, Western Europe became increasingly different from other parts of the world where there was no such religion-state separation and thus power was, at least in theory, "one and undivided."

The Eleventh Century Reform had long-terms consequences. Lord Acton (1877) famously noted that the conflicts between the spiritual and the temporal power continued in subsequent centuries and this led to the rise of civil liberty in Western Europe. In his words, if the two powers had been

\footnotetext{
${ }^{8}$ In the words of Steven Runciman $(1977,4)$, "in contrasting Church with State we are making a distinction which would have been meaningless to the Byzantines." According to Francis Fukuyama (2011, 391-392), the "Byzantine Empire from which Russia drew its model of church-state relations was caesaropapist; the eastern emperor appointed the patriarch of Constantinople and intervened on issues of doctrine." And this was never reformed: "The equivalent of the investiture conflict and the Gregorian reform never took place in the Byzantine world.” See also Møller 2017.
} 
unified, or if one of them had subdued the other, "all Europe would have sunk down under a Byzantine or Muscovite despotism.",9

In short, the institutionalization of church-state separation in the eleventh century became a major turning point in Western European history. In subsequent centuries, Western Europe experienced the establishment of new institutions, particularly universities and corporations, as the bases of rising intellectual and bourgeois classes. ${ }^{10}$ With these institutional and class-based transformations, Western Europe eventually surpassed the Muslim world, in terms of scientific and economic development, as well as religious and philosophical diversity.

\section{Conclusion}

This article analyzes the existence of a certain separation between religious and political authorities in the Muslim world between the eighth and mid-eleventh centuries. Obviously, the separation between them was not absolute: there were many exceptions and entanglements. Nonetheless, religion-state separation was not absolute in the post-eleventh century Catholicism, either. From the Gregorian reforms to the modern West, church-state relations have always contested boundaries and reflected exceptions (Kuru, 2009: ch. 4).

After the mid-eleventh century, even this relative separation between religious and political authorities ended in the Muslim world. Instead, an ulema-state alliance emerged in the Seljuk Empire and later it was adapted and adopted by subsequent Muslim sultanates, including the Ayyubids, Mamluks, Ottomans, Safavids, and Mughals.

Hence, the post-eleventh century Muslim world became similar to early medieval Western Europe, in terms of religion-state relations. In both cases the clerical and military elites dominated society and inhibited the flourishing of intellectuals and merchants. Following the mid-eleventh century, however, Western Europe changed, particularly due to the struggle between the clergy and the royal authority. They tried and failed to dominate one another, which caused the institutionalization of the separation between them. This and other institutional transformations had long-lasting impacts on the increasing intellectual creativity, economic dynamism, and religious diversity in Western Europe.

My analysis reveals the weaknesses of the essentialist claim about Islam and Christianity-that Christianity essentially embraces religion-state separation whereas Islam rejects it. In both Muslim and Christian lands, religion-state relations are changeable and shaped by political actors and conditions. The alliance between the ulema and the state was not an essential part of Islam; instead, it was historically constructed. Similarly, church-state separation in Western Europe was also a result of a historical process. The Orthodox Church had a different historical experience and thus never had a separation from the state. This also shows that the separation between the Catholic Church and the state is not a simple result of the Biblical teaching.

One may still ask, why did Western Europe achieve to institutionalize religion-state separation whereas the Muslim world failed to do so after the eleventh century? To fully answer this question requires a lengthy analysis as I tried in my recent book (Kuru 2019). I can only briefly mention two points here. First, the clergy-state alliance has been the "norm" throughout the world history. What

\footnotetext{
${ }^{9}$ Lord Acton (1877) also regards this as an unintended consequence as neither the Church nor the royal authority strove for separation or liberty. The "aim of both contending parties" was in fact "absolute authority."

${ }^{10}$ The number of Western European universities was twenty, in 1300, it became forty-four in 1400, and it reached sixty-six in 1500 . Buringh and Van Zanden, 2009: 431. See also Collins, 2000: 516.
} 
Muslims achieved from the eighth to the eleventh century and what Western Europeans have achieved after the eleventh century (and particularly after the eighteenth century), in terms of the religion-state separation, are rare experiences. Muslim countries lost that precious accomplishment and Western countries still have that. Second, since the mid-eleventh century, the ulema have declared their alliance with the state as a religious necessity, even a Quranic order (Ibn Taymiyya 1994 [1309-14], 184, 190). Hence, it has been very difficult to challenge it in the Muslim world. Although Islam does not inherently reject religion-state separation, a particular interpretation of Islam preached by the post-eleventh century ulema does.

In general, when religious institutions are separate from the state, they contribute to the increasing socio-political diversity and de-centralization. They legitimize opposition to the government and help the existence of a balance of power between the state and other institutions. Yet, when religious institutions establish an alliance with or become subordinate to the state, they contribute to the increasing socio-political centralization. They delegitimize the opposition and sacralize the government. They also lead to the violation of religious freedom and the oppression of religious dissent. In the case of the Muslim world, the ulema-state alliance has imposed religious restrictions to not only non-Muslims but also dissenting Muslims.

This article does not promote a pessimistic understanding about the future of religious freedom in Muslim-majority countries. In fact, it argues that Islam is not an inherently monistic religion and shows that early Islamic history included examples of a certain religion-state separation. Therefore, it, in fact, promotes optimism. If Muslims decide to separate their religious and governmental institutions, they do not have to search for models exclusively in the West. They can find inspirational examples in their own early history.

\section{References}

Abdel Razek, A. (2012 [1925]). Islam and the Foundations of Political Power. Translated by M. Loutfi. Edited by A. Filali-Ansary. Edinburgh: Edinburgh University Press.

Abdul-Jabbar, G. (2007). Bukhari. New York: Oxford University Press.

Abou El Fadl, K. (2009). Rebellion and Violence in Islamic Law. New York: Cambridge University Press.

Afsaruddin, A. (2008). The First Muslims: History and Memory. Oxford, U.K.: Oneworld.

Ahmed, M. (1968). Muslim Education and the Scholars' Social Status up to the 5th Century Muslim Era (11 ${ }^{\text {th }}$ Century Christian Era) in the Light of Ta'rikh Baghdad. Zurich: Verlag "Der Islam."

Arjomand, S. (1999). "The law, agency, and policy in medieval Islamic society: Development of the institutions of learning from the tenth to the fifteenth century." Comparative Studies in Society and History 41, 2: 263-293.

Al-Ashari. (1953 [c. 935]). Kitab al-Luma': The Luminous Book. Translated by Richard J. McCarthy. In The Theology of al-Ashari. Beirut: Imprimerie catholique.

Ashtor, E. (1976). A Social and Economic History of the Near East in the Middle Ages. London: Collins.

Al-Banna, G. (2003). Al-Islam Din wa Ummah wa Laysa Dinan wa Dawlah. Cairo: Dar al-Fikr al-Islami.

Barthold, W. (1977 [1900]). Turkestan Down to the Mongol Invasion. Translated from Russian by T. Minorsky. London: E. J. W. Gibb Memorial Trust.

Berkey, J. (1992). The Transmission of Knowledge in Medieval Cairo: A Social History of Islamic Education. Princeton: Princeton University Press.

Berman, H. (1983). Law and Revolution: The Formation of the Western Legal Tradition. Cambridge, MA: Harvard University Press.

Berman, H. (2003). Law and Revolution II: The Impact of the Protestant Reformations on the Western Legal Tradition. Cambridge, MA: Harvard University Press.

Bloch, M. (2014 [1940]). Feudal Society. Translated from French by L. Manyon. New York: Routledge.

Bloom, J. (2001). Paper Before Print: The History and Impact of Paper in the Islamic World. New Haven: Yale University Press.

Bloom, J. and S. Blair. (2002). Islam: A Thousand Years of Faith and Power. NewHaven: Yale University Press. 
102 Islam, Catholicism, and Religion-State Separation: An Essential or Historical Difference?

Bonner, M. (2010). “The waning of empire: 861-945.” In C. Robinson, ed., The New Cambridge History of Islam. Vol. 1: The Formation of the Islamic World. Sixth to Eleventh Centuries. New York: Cambridge University Press.

Botticini, M. and Z. Eckstein. (2012). The Chosen Few: How Education Shaped Jewish History, 70-1492. Princeton: Princeton University Press.

Braudel, F. (1982). Civilization and Capitalism, 15th-18th Century. Volume 2: The Wheels of Commerce. Translated from French by Sian Reynolds. New York: Harper and Row.

Bulliet, R. (2009). Cotton, Climate, and Camels: A Moment in World History. New York: Columbia University Press.

Buringh, E. and J. van Zanden. (2009). "Charting the 'rise of the West': Manuscripts and printed books in Europe. A long-term perspective from the sixth through eighteenth centuries." The Journal of Economic History 69, 2: 409-445.

Cahen, C. (1953). "L'évolution de l'iqta du IXe au XIIIe siècle: contribution à une histoire comparée des sociétés médiévales. Annales. Économies, Sociétés, Civilisations 8, 1: 25- 52.

Chandler, T. (1987). Four Thousand Years of Urban Growth: An Historical Census.Lewiston, NY: Edwin Mellen Press.

Cohen, H. (1970). "The economic background and the secular occupations of Muslim jurisprudents and traditionists in the classical period of Islam (Until the middle of the eleventh century)." Journal of the Economic and Social History of the Orient 13, 1: 16-61.

Collins, R. (2000). The Sociology of Philosophies: A Global Theory of Intellectual Change. Cambridge, MA: Harvard University Press.

Corbin, H. (1986). Histoire de la philosophie islamique. Paris: Gallimard.Crone, P. and M. Hinds. (1986). God's Caliph: Religious Authority in the First Centuries of Islam. New York: Cambridge University Press.

Djaï, H. (1989). La grande discorde: Religion et politique dans l'islam des origins. Paris: Gallimard.

Elias, N. (2000 [1939]). The Civilizing Process. Translated from German by E. Jephcott. Malden, MA: Blackwell.

Ephrat, D. (2000). A Learned Society in a Period of Transition: The Sunni 'Ulama' of Eleventh-Century Baghdad. Albany: SUNY Press.

Fadel, M. (2011). “A tragedy of politics or an apolitical tragedy?” Journal of the American Oriental Society 131, 1: 109-127.

Fakhry, M. (2004). A History of Islamic Philosophy. New York: Columbia University Press.

Fox, J. (2020). Thou Shalt Have No Other Gods before Me: Why Governments Discriminate against Religious Minorities. New York: Cambridge University Press.

Fukuyama, F. (2011). The Origins of Political Order: From Prehuman Times to the French Revolution. New York: Farrar, Straus and Giroux.

Al-Ghazali. (1999 [1095]). The Infamies of the Batinites and the Virtues of the Mustazhirites (Fada'ih al-Batiniyya wa Fada'il al-Mustazhiriyya). Partially translated and edited by R. McCarthy. In Freedom and Fulfillment. Deliverance from Error: Five Key Texts Including His Spiritual Autobiography, al-Munqidh min al-Dalal. Louisville, KY: Fons Vitae.

-------. (2000 [1095]). The Incoherence of the Philosophers [Tahafut al-Falasifa]. Translated by M. Marmura. Provo, UT: Brigham Young University.

-----. (2013 [1095]). Moderation in Belief (Al-Iqtisad fi al-I'tiqad). Translated by A. Yaqub. Chicago: University of Chicago Press.

------. (2015 [c. 1097]). Kitab al-'Tlm: The Book of Knowledge. Book 1 of the Ihya' 'Ulum al-Din: The Revival of the Religious Sciences. Translated and edited by K. Honerkamp. Louisville: Fons Vitae.

------. (2002 [c. 1105]). The Decisive Criterion for Distinguishing Islam from Masked Infidelity (Faysal al-Tafriqa bayna al-Islam wa al-Zandaqa). Translated and edited by S. Jackson. In On the Boundaries of Theological Tolerance in Islam: Abu Hamid al-Ghazali's Faysal al-Tafriqa. Karachi: Oxford University Press.

Glick, T. (2005). Islamic and Christian Spain in the Early Middle Ages. Boston: Brill.

Goddard, H. (2000). A History of Christian-Muslim Relations. Chicago: New Amsterdam Books.

Goitein, S. (1966a). "The Rise of the Middle-Eastern Bourgeoisie in Early Islamic Times.” In S. D. Goitein, Studies in Islamic History and Institutions. Leiden: Brill.

Goitein, S. (1966b). "The Mentality of the Middle Class in Medieval Islam.” In S. D. Goitein, Studies in Islamic History and Institutions. Leiden: Brill.

Hanne, E. (2007). Putting the Caliph in His Place: Power, Authority, and the Late Abbasid Caliphate. Madison, NJ: Farleigh Dickinson University Press. 
Harris, M. (1995). History of Libraries in the Western World. London: The Scarecrow Press.

Hodgson, M. (1974a). The Venture of Islam: Conscience and History in a World Civilization. Vol. 1: The Classical Age of Islam. Chicago: University of Chicago Press.

Hodgson, M. (1974b). The Venture of Islam: Conscience and History in a World Civilization. Vol. 2: The Expansion of Islam in the Middle Periods. Chicago: University of Chicago Press.

Huntington, S. (1996). The Clash of Civilizations and the Remaking of World Order. New York: Simon and Schuster.

Ibn Khaldun. (1967 [1377]). The Muqaddimah: An Introduction to History. Vols. I-III. Translated by Frantz Rosenthal. New York: Pantheon Book.

Ibn Khaldun. (2005 [1377]). The Muqaddimah: An Introduction to History. Translated by Frantz Rosenthal. Abridged and edited by N. J. Dawood. Princeton: Princeton University Press.

Ibn Taymiyya, Abu al-Abbas Ahmad. (1994 [1309-14]). Al-Siyasah al-Shar'iyah fi Islah al-Raci wa al-Ra'iyah. Algiers: Editions ENAG.

Inalc1k, H. (2000 [1973]). The Ottoman Empire: The Classic Age, 1300-1600. Translated by Norman Itzkowitz and Colin Imber. London: Phoenix.

İnalc1k, H. (1994). “The Ottoman state: Economy and society, 1300-1600.” In H. İnalc1k with D. Quataert, eds., An Economic and Social History of the Ottoman Empire. Vol. I: 1300-1600. New York: Cambridge University Press.

Joseph, G. (2000). The Crest of the Peacock: Non-European Roots of Mathematics. Princeton: Princeton University Press.

Kennedy, H. (2005). When Baghdad Ruled the Muslim World: The Rise and Fall of Islam's Greatest Dynasty. Cambridge, MA: Da Capo Press.

Kilgour, F. (1998). The Evolution of the Book. New York: Oxford University Press.

Kuran, T. (2011). The Long Divergence: How Islamic Law Held Back the Middle East. Princeton: Princeton University Press.

Kuru, A. (2009). Secularism and State Policies toward Religion: The United States, France, and Turkey. New York: Cambridge University Press.

------. (2019). Islam, Authoritarianism, and Underdevelopment: A Global and Historical Comparison. New York: Cambridge University Press.

------. (2020). "Execution for a Facebook post? Why blasphemy is a capital offense in some Muslim countries." The Conversation, February 20, https://theconversation.com/execution-for-a-facebook-post-why-blasphemy-is-acapital-offense-in-some-muslim-countries-129685.

Lambton, A. (1981). State and Government in Medieval Islam. An Introduction to the Study of Islamic Political Theory: The Jurists. New York: Oxford University Press.

------. (1991). Landlord and Peasant in Persia: A Study of Land Tenure and Land Revenue Administration. New York: I.B. Tauris.

Lapidus, I. (1975). “The separation of state and religion in the development of early Islamic society." International Journal of Middle East Studies 6, 4: 363-85.

------. (1984). Muslim Cities in the Later Middle Ages. New York: Cambridge University Press.

---. (1996). "State and religion in Islamic societies." Past and Present 151, 1: 3-27.

-----. (2002). A History of Islamic Societies. New York: Cambridge University Press.

"Le Testament d'Ardasir." (1966). Arabic-French text edited and translated by M. Grignaschi. In "Quelques spécimens de la littérature sassanide conservés dans les bibliothèqes d'Istanbul.” Journal Asiatique 254: 46-90.

Lewis, B. (1991). The Political Language of Islam. Chicago: University of Chicago Press.

Lindberg, D. (1976). Theories of Vision from Al-Kindi to Kepler. Chicago: University of Chicago Press.

Logan, F. Donald. (2013). A History of the Church in the Middle Ages. New York: Routledge.

Lombard, Maurice. (1975). The Golden Age of Islam. Translated from French by J. Spencer. New York: American Elsevier Publishing.

Lord Acton. (1877). "The History of Freedom in Christianity." An Address Delivered to the Members of the Bridgnorth Institute, May 28, https://www.acton.org/research/history-freedom-christianity.

Maçoudi. (1863 [947]). Les prairies d'or [Muruj al-Dhahab]. Vol. II. Arabic-French text edited and translated by C. de Meynard and P. de Courteille. Paris: L'imprimerie imperial.

Maddison, A. (2004). Growth and Interaction in the World Economy: The Roots of Modernity. Washington, D.C.: The AEI Press. 
104 Islam, Catholicism, and Religion-State Separation: An Essential or Historical Difference?

Mahoney, J. and D. Rueschemeyer. (2003). Comparative Historical Analysis in the Social Sciences. New York: Cambridge University Press.

Melchert, C. (2006). Ahmad ibn Hanbal. Oxford, U.K.: Oneworld.

Mez, A. (1937). The Renaissance of Islam. Translated from German by S. Bakhsh and D. Margoliouth. Patna, India: Jubilee Printing and Publishing House.

Møller, J. (2017). "Medieval origins of the rule of law: The Gregorian reforms as critical juncture?” Hague Journal on the Rule of Law 9: 265-282.

Morony, M. (1984). Iraq after the Muslim Conquest. Princeton: Princeton University Press.

Mottahedeh, R. (1980). Loyalty and Leadership in an Early Islamic Society. Princeton: Princeton University Press.

Al-NadiM. (1970 [987]). The Fihrist of al-Nadim: A Tenth-Century Survey of Muslim Culture. Vol I-II. Translated and edited by Bayard Dodge. New York: Columbia University Press.

Nadwi, M. (2010). Abu Hanifah: His Life, Legal Method and Legacy. Oxford: Kube and Interface Publications.

Nizam al-Mulk. (1978 [c. 1090]). The Book of Government or Rules for Kings. The Siyar al-Muluk or Siyasat-nama of Nizam al-Mulk. Translated from Persian by H. Darke. Boston: Routledge and Kegan Paul.

Pew Research Center. (2019). "A Closer Look at How Religious Restrictions Have Risen Around the World.” July 15. https://www.pewforum.org/2019/07/15/a-closer-look-at-how-religious-restrictions-have-risen-aroundthe-world/.

Philpott, D. (2019). Religious Freedom in Islam: The Fate of a Universal Human Right in the Muslim World Today. New York: Oxford University Press.

Pormann, P. and E. Savage-Smith. (2007). Medieval Islamic Medicine. Washington, D.C.: Georgetown University Press.

Rahman, F. (1968). Islam. New York: Anchor Books.

Rosenthal, E. (1958). Political Thought in Medieval Islam: An Introductory Outline. Cambridge University Press.

Runciman, S. (1977). The Byzantine Theocracy. Cambridge: Cambridge University Press.

Shahrastani, M. (1984 [c. 1127]). Muslim Sects and Divisions. The Section on Muslim Sects in Kitab al-Milal wa '1Nihal. Translated by A. K. Kazi and J. G. Flynn. Boston: Kegan Paul International.

------. (1986 [c. 1127]). Livre des religions et des sects. Vol. I [Kitab al-Milal wa '1-Nihal]. Translated into French by D. Gimaret and G. Monnot. Paris: Peeters, UNESCO.

Shatzmiller, M. (2011). "Economic performance and economic growth in the early Islamic world." Journal of the Economic and Social History of the Orient 54, 2: 132-184.

Southern, R. (1970). Western Society and the Church in the Middle Ages. New York: Penguin Books.

Starr, F. (2013). Lost Enlightenment: Central Asia's Golden Age from the Arab Conquest to Tamerlane. Princeton: Princeton University Press.

Tierney, B. (1988 [1964]). The Crisis of Church and State: 1050-1300. Toronto: University of Toronto Press.

--.. (1982). Religion, Law, and the Growth of Constitutional Thought 1150-1650. Cambridge: Cambridge University Press.

Van Zanden, J. (2009). The Long Road to the Industrial Revolution: The European Economy in a Global Perspective, 1000-1800. Leiden: Brill.

Watson, A. (1983). Agricultural Innovation in the Early Islamic World: The Diffusion of Crops and Farming Techniques, 700-1100. New York: Cambridge University Press.

Zaman, M. (1997). Religion and Politics under the Early 'Abbasids: The Emergence of the Proto-Sunni Elite. Leiden: Brill. 